\title{
DO PERCEIVED CULTURE PERSONALITY TRAITS LEAD TO A MORE FAVOURABLE RATING OF COUNTRIES AS TOURIST DESTINATIONS?
}

\section{DOVODI LI PERCIPIRANA OSOBNOST KULTURE DO POVOLJNIJIH OCJENA ZEMALJA KAO TURISTIČKIH DESTINACIJA?}

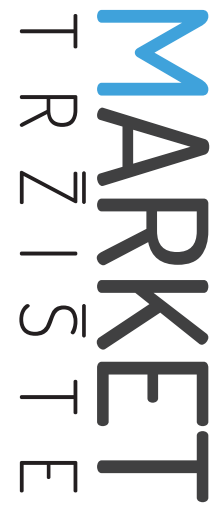

Market-Tržište

Vol. 30, No. 1, 2018, pp. 77-91

UDK 338.487:658.8

DOI http://dx.doi.org/10.22598/mt/2018.30.1.77

Original scientific paper

\begin{abstract}
Tamás Gyulavária, Erzsébet Malota ${ }^{\mathrm{b}}$
a) Corvinus University of Budapest, Marketing and Media Institute, Fővám tér 8., 1093 Budapest, HUNGARY, tamas.gyulavari@ uni-corvinus.hu

b) Corvinus University of Budapest, Marketing and Media Institute, Fővám tér 8., 1093 Budapest, HUNGARY, erzsebet.malota@ uni-corvinus.hu
\end{abstract}

\begin{abstract}
Purpose - The main purpose of our study was to investigate the effect of perceived culture personality (CP) on the evaluation of a country as an ideal tourist destination. A new culture personality scale has been developed for the analysis, and this paper aims to implement it in a destination marketing context.
\end{abstract}

Design/Methodology/Approach - As a result of the scale construction procedure, based on extensive qualitative studies, a 51-item semantic differential scale was developed and tested. A sample of 216 Hungarian and 47 French university students has been surveyed.

Findings and implications - The regression model proves the connections between perceived culture personality and the evaluation of a culture as a tourist destination. The most influencing personality traits of the culture are also identified. Based on the results, destination managers can refine their marketing communication plan, especially among younger target segments.

Limitations - The generalizability of the results is subject to some limitations due to the student sample used.

\section{Sažetak}

Svrha - Glavna svrha našeg istraživanja bila je istražiti učinak percipirane osobnosti kulture (culture personality - CP) na procjenu zemlje kao idealnog turističkog odredišta. Za potrebe analize razvijena je nova ljestvica osobnosti kulture, a cilj rada jest implementirati ju u kontekst marketinga destinacije.

Metodološki pristup - Kao rezultat procedure izrade skale, temeljene na opsežnim kvalitativnim studijama, razvijena je i testirana skala semantičkog diferencijala s 51 česticom. Anketiran je uzorak od 216 mađarskih i 47 francuskih studenata.

Rezultati i implikacije - Regresijski model dokazuje povezanost percipirane osobnosti kulture i njezine procjene kao turističke destinacije. Isto su tako uočena najutjecajnija obilježja osobnosti kulture. Na temelju rezultata menadžeri destinacija mogu razraditi svoj plan marketinške komunikacije, osobito za segmente mlađih ciljnih skupina.

Ograničenja - Generalizacija rezultata ograničena je s obzirom na studentski uzorak ispitanika. 
Originality - Both the scale developed and the effects revealed contribute to the research field.

Keywords - culture personality (CP), tourist destinations, scale development
Doprinos - Razvijena skala i otkriveni utjecaji daju doprinos istraživačkom području.

Ključne riječi - osobnost kulture, turističke destinacije, razvoj skale 


\section{INTRODUCTION AND OBJECTIVES}

In marketing practice, one is often exposed to advertising, which tries to make an impact on the audience with the help of a personality built around the object of communication. The concept of personality attracted attention among researchers in marketing when very similar products resulting from mass production started to appear on the market and brand managers faced a great challenge regarding their positioning strategy. The quality parameters of products started to be identical and differences could have been achieved only in case of irrelevant product attributes which were not perceived or noticed during the process of information provision to customers. Practitioners soon realized that products can efficiently be distinguished on the basis of brand personalities, person-related associations or abstract traits (McEnally \& De Chernatony, 1999), especially because in most cases this kind of differentiation required less investment than the product development process (Azoulay \& Kapferer, 2003; Péter, Németh \& Kaszás, 2014a; Péter, Németh \& Kaszás, 2014b). Another advantage of this kind of symbolic positioning is that, in case of simple products with only few relevant attributes, personality as a complex and diverse concept provides a wide range of possibilities to build and express uniqueness.

Similar processes can be observed in the case of marketing in tourism as well. The concept of country image, country branding and destination marketing have recently gained more attention in international academic research in marketing, relying on the achievements of brand personality concepts and theories. However, the more nationalities live in a country, the more differences can be observed there; these nationalities have their own cultural specialties and they are perceived along different personality traits. Papp-Váry (2008, p. 134) emphasizes that "the higher the speed of information diffusion gets, the more similar countries will be- come. The difference, which is the most important factor in (country) brand management, can be gained by those unique and special characteristics of the culture that are deeply rooted and embedded in a country." The importance of the culture component of destinations as a touristic product is also increasing (Bodnár, Jászberényi \& Ásványi, 2017), and destinations should be able to adjust their offer according to the needs of their targets with different social characteristics (Keller, 2017).

The main objective of the present research is to investigate the relationship between perceived culture personality and the attractiveness of that culture as a tourist destination. To determine the existence and nature of this association, a new culture personality scale was developed to also present how a culture can be described using personality traits. Accordingly, the following research questions were set:

o How can we describe the French and the Hungarian culture with personality traits?

- Are there differences in how the French and the Hungarians perceive the other's culture personality?

- Can dimensions of culture personality be identified?

- Which personality traits influence the evaluation of the culture as a tourist destination to the largest extent?

\section{LITERATURE REVIEW}

\subsection{The culture personality concept}

The culture personality concept can be originated from the general brand personality literature and from the view of a broader approach; it is a special version of brand image. Several scholars investigated the ways in which brand image concept can be adapted to countries. This research field has been investigated from different perspectives. Country of origin image (COO), or "made-in-image" as it is sometimes

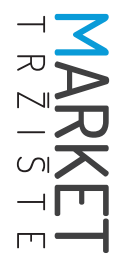


called, has been considered mainly as a cue influencing consumers' brand choice (Heslop, Papadopoulos \& Bamossy, 1993; Berács \& Gyulavári, 1999; Papadopoulos \& Heslop, 2014). General country image has been researched within the scope of potential international financial and/or manufacturer investment. Country image plays an important role in the destination research too, where the concept has been studied as a special case of destination image (Sun, 2016). There are attempts to shift this phenomenon to a more abstract level and integrate the abovementioned research efforts into one general concept of country equity (Roth \& Diamantopoulos, 2009).

In the country image model of Heslop and others (1993), the image of the country and one of the people living there are handled as two different - but strongly correlated - concepts. People's image is not considered as part of the country image but can be interpreted through other dimensions. Hosany, Ekinci and Uysal (2004) investigated the relationship between destination image and destination personality and concluded that the two concepts are correlated. They found that the emotional components of destination image capture the majority of variance on destination personality dimensions, as measured by Aaker's (1997) brand personality scale.

In our study, among these intercorrelated concepts we focus on a new one that we named "culture personality." Instead of brand or country, we selected culture as the core object of our investigation before focusing, in a wide array of image components, on personality traits. We define culture personality as a set of human characteristics associated with a culture.

Personality has been conceptualized in many different ways. Diverse approaches have emerged in the literature, depending on assumed antecedents of the concept that can presumably be biological, psychoanalytical, or evolutionary etc. One of the most popular directions of various research streams is the trait theory that emphasizes the stable and inherited character- istics of a person and focuses primarily on the measurement of these traits. The pioneering researcher of this theory was Allport (1937, p. 48.), who collected 49 definitions of personality to analyze and classify. Based on that work, he developed his own definition: "personality is the dynamic organization within the individual of those psychophysical systems that determine his unique adjustments to the environment." This description reveals the nature of the concept that can hardly be captured in a precise manner and, by necessity, researchers are forced to define it on a rather general level. Despite some weaknesses of the theoretical background, the trait theory evolved into the most dominant approach to investigating personality. This can be attributed to the strong measurement orientation and the attention paid to the development of applicable scales.

\subsection{Relationship between culture personality and attitudes towards a destination}

A multitude of similar concepts regarding destination image have been researched in regard to their effect on the attitude towards destination or the behavioral intention to visit. That relationship is well-established in the destination literature (Zhang, Fu, Cai \& Lu, 2014; Malota \& Gyulavári, 2014). However, only a few empirical research studies have been carried out to analyze the impact of the personality components of destination image. Búrcio, Silva and Salgueiro (2014) found a positive relationship between destination personality and behavioral intentions to visit while including affective country image as a mediating variable. Papadimitriou, Apostolopoulou and Kaplanidou (2013) also considered destination personality as an antecedent of general image and found empirical support for its indirect effect on the intention to visit.

Another stream of destination research involves the self-congruity theory in the investigation of a relationship between the perceived personality of destinations and the tendency to visit 
(Murphy, Benckendorff \& Moscardo, 2007; D'Astous \& Boujbel, 2007; Usakli \& Baloglu, 2011), as the researchers examined the role of different types of self-image of tourists in the attitude formation towards destinations. D'Astous and Boujbel (2007) developed a new scale to measure country personality and test the validity of it with the help of congruity theory. Murphy and others (2007) found a link between destination brand personality and travel motivation but they concluded that the strength of the association varies between consumer segments. Usakli and Baloglu (2011) suggest that the actual and the ideal self-image have unequal effects in the context of destination evaluation. The actual self-image plays a role in a higher probability of return of consumers if a destination is perceived similar to their self, but tourists recommend those destinations that are perceived consistent with their ideal self-image.

\section{METHOD}

\subsection{General and marketing-related personality scales in the literature}

\section{General personality scales}

The efforts that the followers of trait theory made to construct a valid and generally applicable measure of personality can be demonstrated by the lexical method they used. Allport and Odbert (1936), for instance, collected almost 18,000 phrases that are found in the dictionary to describe the differences in the behavior of individuals. This list incorporated phrases of temporal mood and subjective evaluation of a person which were sorted out later. Cattel (1945) continued the work of Allport and Odbert by reducing the number of traits dramatically to 22 items and subsequently identified 16 personality factors (see Cattel, Eber \& Tatsuoka, 1970). Fiske (1949) was the first to publish five factors using Cattel's items and, despite questioning different types of respondents (self-evaluators, class fellows, psychologists), he managed to achieve the same structure. Tupes and Christal (1961) also obtained the five-factor model and other researchers confirmed the results. This became the origin of the most widely recognized measure of personality, the Big Five (John \& Srivastava, 1999). In addition to the five-factor model of personality, different numbers of dimensions can be found in the literature, such as the six-factor model of Ashton and Lee, and the three-factor model of Eysink (Linden, Nijenhuis \& Bakker, 2010). Researchers have recently investigated the possibility of more common dimensions or a single universal one, named the General Factor of Personality (GFP; Linden et al., 2010).

Although the researchers made tremendous efforts to find a generally accepted, context-free scale with common dimensions of personality, another trend can be observed in the literature. The demand for more and more sophisticated measurement and the fit requirements of complex models requires the adaption of general scales or the development of new ones that are more valid regarding a specific field of research interest.

\section{Marketing-related personality scales}

The measurement tools of personality applied in the field of marketing can be classified into two groups, so we can distinguish brand personality and country personality scales. In the latter case, the personality is often part of a broader concept of a model and can be viewed as a dimension of country image, country-of-origin image, or country brand equity (see Berács \& Gyulavári, 1999; Berács, Gyulavári, Heslop \& Papadopoulos, 2000; Malota, 2003; Roth \& Diamantopoulos, 2009; Jenes, 2012).

In the marketing literature, one of the most recognized personality scale was developed by Aaker (1997), who constructed a new measurement to brand personality. She perceived that two types of scales were applied at that time to measure the personality of a brand. On the one hand, many of them were formulated in a haphazard fashion for a given business research

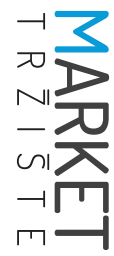




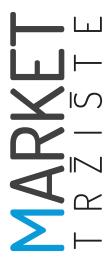

project; on the other hand, general psychological scales were implemented. In case of the latter, not all the items were evaluated as relevant for a brand and additional characteristics were viewed to be important that were originally not part of the personality concept. Age as a demographic characteristic, for instance, is not a personality trait but is related to the perceived image of a person, and this symbolic attribute plays important role in the buying decisions of customers. Once marketing managers decide to position the brand upon personality, e.g. with the help of celebrity endorsers, they cannot neglect this characteristic. For this reason, Aaker developed her own brand personality scale and generated items from three different sources: a) general personality scales, b) scales used by market research agencies, c) qualitative research carried out for this target. The 309 items collected this way were reduced to the final 45 , which represent 15 facets across five dimensions.

D'Atsous and Boujbel (2007) also aimed to create a specific personality scale, one that is more appropriate for measuring the perceived personality of a country than general scales. They developed a six-factor scale and tested its nomological validity in the framework of the congruency theory; that is, whether the similarity between self-image and country image leads to stronger preferences. The perceived personality of a country and a culture is highly correlated but differences can also be identified. The most obvious one is related to the natural characteristics of a country which can be part of the country image. The expressions such as "Mother Nature" and "the wild" used in the English and Hungarian language well demonstrate the tendency to describe things with personal attributes. Nature itself, however, is rarely represented in the concept of culture. In conclusion, country personality and culture personality are overlapping but still different concepts. From the aspect of measurement, country image has other elements which are hard to personalize, e.g. economic, political, geographical dimension. For this reason, a personality scale works better in the case of culture. Hofmeister, Neulinger and Kunsági (2002) investigated personality in different cultural settings.

\subsection{Culture personality scale construction}

Following the recommendation of the methodological literature (Churchill, 1979; Rossiter, 2002), after defining the concept to measure we started the culture personality (CP) scale construction procedure by generating items via exploratory methods (see Gyulavári et al., 2014). Qualitative data were collected during each semester between 2004 and 2012 among foreign exchange students, who answered the following question: "Culture is often thought of as the personality of the society. If your culture was a person, how would you describe its personality traits?". Altogether 520 culture personality descriptions (about 42 different cultures) were generated this way and, based on the most frequently used adjectives, a list of personality traits was prepared.

In 2012, two control methods for these scale items were used. We conducted 48 personal interviews with MBA students and, subsequently, 70 international business majors were asked to discuss cultural descriptions in small groups after lectures as part of the intercultural communication course on theoretical models of culture. Utilizing the results of these above mentioned three methods, a 51-item bipolar scale was developed (Malota \& Gyulavári, 2012).

Opposite adjectives of the semantic differential scale were examined and content validity was checked. Before translating the scale items to English and French, interviews with linguistic experts were conducted. The real content and interpretations of the adjectives were then discussed with bilingual translators. This way - besides resembling different versions of parallel translations - the interpretations of Hungarian adjectives were double-checked. To finalize the scale items, we employed psychologists, economists, native speaker translators, and bilingual proof readers. 


\subsection{Quantitative data collection}

After the exploratory phase, the final 51-item scale was tested using quantitative method. An online survey was conducted among a convenience sample of 216 Hungarian and 47 French business university students. French students were participants of an exchange program and spent one semester in Hungary, while Hungarian students were regular students at the university. Female respondents were slightly more numerous (57\%) than male participants (43\%), and the age of participants in the sample ranged from 21 to 24 years.

Both groups were asked to rate the personal traits of French and Hungarian cultures on a 7-point semantic differential scale, with the following introduction: "Please rate French and Hungarian culture as a person, using the following scales." Both groups filled in the questionnaire first regarding their own culture and then regarding the other culture.
Afterwards, both samples were asked to evaluate the other culture as an ideal tourist destination on a single-item ("To what extent do you think Hungary/France is an ideal touristic destination for you?"), 7-point semantic differential scale (not at all - absolutely) and, finally, demographic questions were asked.

\section{RESULTS}

\subsection{Polarity profiles of perceived culture personalities of France and Hungary among Hungarian and French respondents}

In the this section, we elaborate on those personality traits that show significant differences in means among French and Hungarian respondents $(p \leq 0.05)$. Figure 1 shows the personality traits of French culture that were perceived to be significantly different by the French and the Hungarians, and we found 22 significant differences ( $p \leq 0.05)$.

FIGURE 1: Significant differences in the evaluation of French culture personality traits in view of the means given by Hungarian and French respondents

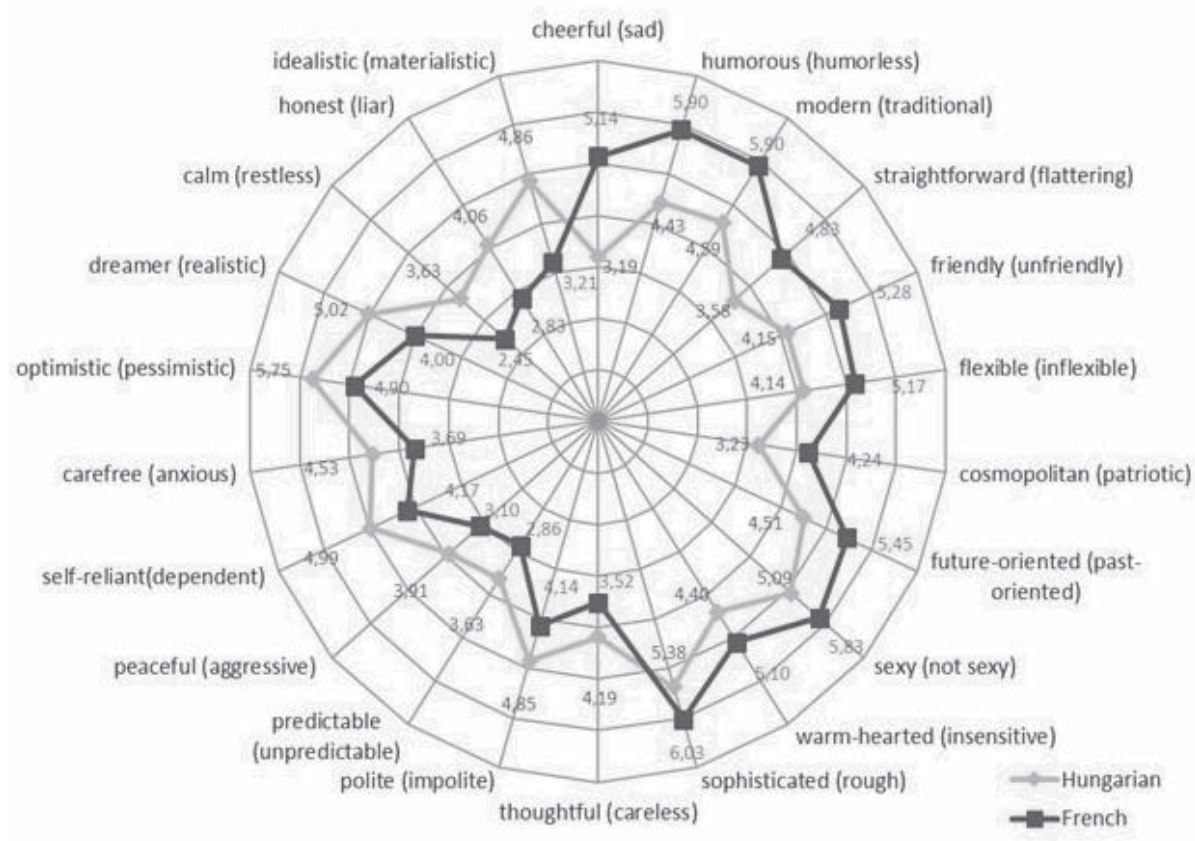


Hungarians perceive the French to be calmer, more honest, optimistic, peaceful, thoughtful, dreamer, polite, predictable, self-reliant, carefree, and idealistic than the French see themselves. Also, the Hungarians label the French culture personality as being sadder, less friendly, less humorous, less modern, less sexy, less flexible, less straightforward, less cosmopolitan, less future-oriented, less warm-hearted, and less sophisticated than the French.

The opposite trait of the semantic differential scale is shown in parenthesis, meaning the negative pole of the scale: 1 on 1-7.

Figure 2 presents remarkable differences of the Hungarian culture's evaluations regarding quite a lot of attribute pairs: out of 51 pairs, 24 significant differences were found.

The French describe the Hungarian culture as more rational, thrifty, industrious, selfless, calm, feminine, future-oriented, optimistic, carefree, stable, and self-reliant than Hungarians see themselves. On the other hand, the Hungarian culture is perceived to be smarter, more liberal, indulgent, dreamer, passionate, unique, proud, polite, colorful, friendly, warm-hearted cheerful, and more humorous by the Hungarians themselves than by the French respondents.

The opposite trait of the semantic differential scale is shown in parenthesis, meaning the negative pole of the scale: 1 on 1-7.

\subsection{Dimensions of culture personality}

Here, dimensions of the culture personality scale will be examined only for those items that are correlated to the evaluations of the country as an ideal tourist destination. Hungarian respondents' perception of the French culture

FIGURE 2: Significant differences in the evaluation of Hungarian culture personality traits in view of the means given by Hungarian and French respondents

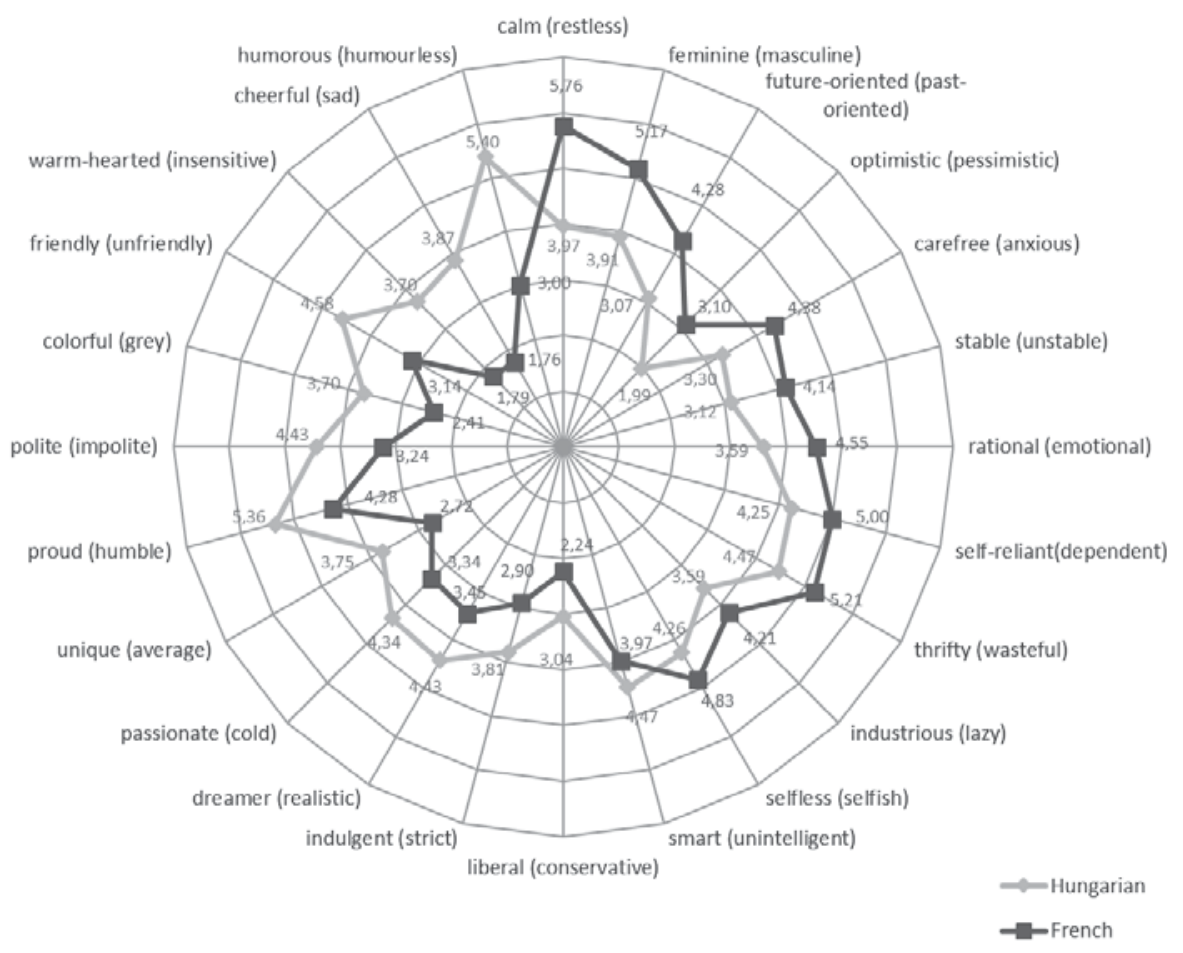


personality traits was included in the analysis to reveal the underlying dimensions.

For this stage of research, exploratory factor analysis was decided to be appropriate (as opposed to confirmatory factor analysis). Principal components analysis (PCA) was completed for the following 29 items incorporating a varimax axis rotation (VAR). The correlation of variables was confirmed by calculating $\mathrm{KMO}$ values (0.883) and by Bartlett's test that proved it to be significant.

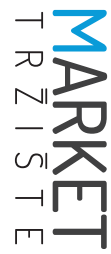

TABLE 1: Factor structure of the culture personality scale (ideal tourist destination items)

\begin{tabular}{|c|c|c|c|c|c|c|c|}
\hline \multirow{2}{*}{ Factors } & \multirow{2}{*}{ Factor items } & \multicolumn{6}{|c|}{ Component } \\
\hline & & 1 & 2 & 3 & 4 & 5 & 6 \\
\hline \multirow{7}{*}{ Competence } & Well-organized-disorganized & .732 & & & & & \\
\hline & Perfectionist-negligent & .718 & & & & & \\
\hline & Stable-unstable & .568 & & & & & \\
\hline & Aimless-ambitious & -.554 & & & & & \\
\hline & Lazy-industrious & -.548 & & & & & \\
\hline & Smart-unintelligent & .513 & & & & & \\
\hline & Educated-uneducated & .499 & & & & & \\
\hline \multirow{6}{*}{ Life approach } & Anxious-carefree & & -.812 & & & & \\
\hline & Optimistic-pessimistic & & .791 & & & & \\
\hline & Passive-dynamic & & -.532 & & & & \\
\hline & Dependent-self-reliant & & -.497 & & & & \\
\hline & Idealistic-materialistic & & .467 & & & & \\
\hline & Petty-generous & & -.454 & & & & \\
\hline \multirow{7}{*}{ Aura (visible style) } & Humorless-humorous & & & -.671 & & & \\
\hline & Passionate-cold & & & .599 & & & \\
\hline & Sexy-not sexy & & & .588 & & & \\
\hline & Warm-hearted-insensitive & & & .577 & & & \\
\hline & Colorful-grey & & & .544 & & & \\
\hline & Unfriendly-friendly & & & -.514 & & & \\
\hline & Unique-average & & & .492 & & & \\
\hline \multirow{5}{*}{$\begin{array}{l}\text { Interpersonal } \\
\text { approach }\end{array}$} & Aggressive-peaceful & & & & .686 & & \\
\hline & Polite-impolite & & & & -.619 & & \\
\hline & Selfish-selfless & & & & .554 & & \\
\hline & Liar-honest & & & & .516 & & \\
\hline & Intolerant-tolerant & & & & .515 & & \\
\hline \multirow{2}{*}{ Humble collectivism } & Humble-proud & & & & & -.691 & \\
\hline & Individualistic-collectivistic & & & & & .559 & \\
\hline \multirow{2}{*}{ Rectitude } & Coward-brave & & & & & & .711 \\
\hline & Straightforward-flattering & & & & & & -.445 \\
\hline \multicolumn{2}{|c|}{ EXPLAINED VARIANCE BY THE FACTOR } & $11 \%$ & $11 \%$ & $11 \%$ & $10 \%$ & $6 \%$ & $5 \%$ \\
\hline \multicolumn{2}{|c|}{ CRONBACH'S ALPHA } & 0.79 & 0.75 & 0.76 & 0.68 & 0.30 & 0.39 \\
\hline
\end{tabular}




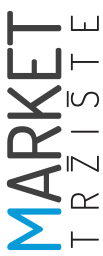

According to the anti-image matrix, the measures of sampling adequacy (MSA) values of all variables are within the correct interval, above 0.770 , providing the basis for the variables to be included in the analysis. The number of factors was determined on the basis of the "eigenvalue greater than 1" criterion and it resulted in six factors. The total variance explained by these 6 factors was equal to 54 percent. The results of the factor analysis are provided in Table 1.

The first four factors - "competence", "life approach", "aura", and "interpersonal approach" explain almost the same amount of sample variance, $10-11 \%$ each. These factors are easy to interpret as they can likely be considered general factors for any culture's personality, whilst the last two seem to be less general factors. The first factor named "competence" includes skills and competencies, e.g. stability, ambition, intelligence, etc. The second consists of traits that show some kind of "life approach", such as being optimistic, dynamic, idealistic, etc. The third factor is named "aura", its variables expressing distinctive but intangible quality traits like sexiness, passion, humor, uniqueness that seem to surround a person. The fourth factor, "interpersonal approach" includes elements related to how a person approaches others, e.g. with tolerance, honesty, politeness. The last two factors, including only two variables each, are named "humble collectivism" and "rectitude".

The last row of Table 1 shows the reliability of the scales. The Cronbach's Alpha values for the reliability of the dimensions are high, proving their inner consistency, except for the last two dimensions that consist of 2 items only.

As easy applicability in practice requires further reduction of scale items, we selected the 24 attributes that had been determined to be significantly correlated with the evaluation of France as a touristic destination, that is, the items that are more relevant from this point of view. Compared with the previous analysis, where all personality scale items correlating with ideal tourist destination evaluations were included, we can conclude that the factors of this $2^{\text {nd }}$ analysis (items correlating only with tourist evaluations) are stable and show only minor modifications from the previous findings. The "life approach" and "aura" dimensions remained exactly the same, with the same variables loading to the factor (except for the "dependent-self-reliant" variable, which does not correlate with countries being perceived as ideal tourist destinations, so it was excluded from this analysis). The "interpersonal approach" factor also remained the same as in the previous analysis, except that it does not contain the "liar-honest" variable, as this variable strengthens our last factor "rectitude", together with "lazy-industrious", making it more stable and understandable. The "competence" dimension also consists of the same variables as previously.

\subsection{Effect of culture personality on the evaluation of France as a tourist destination}

One of the research questions in the focus of our study was which personality traits influence the consideration of a country (in our case France) as an ideal tourist destination. France is considered quite an ideal destination from the tourist point of view (with a mean of 5.00, measured on a 7-point scale).

For the French, Hungary is also an ideal tourist destination (5.04). It is worth noting that French respondents spent 3.5 months in Hungary as exchange students so they have some experience regarding the country.

Correlation coefficients can be found in Table 2. As the sample size of French respondents is quite small, we discuss only the results for France, i.e. which personality traits correlate with the evaluation of France as an ideal destination for Hungarians.

We found correlations with 24 variables in the case of tourist destination; honesty was the most important culture personality trait with the highest correlation coefficients. 
TABLE 2: France as an ideal tourist destination in view of its culture personality traits

\begin{tabular}{|l|c|}
\hline $\begin{array}{l}\text { Culture } \\
\text { personality } \\
\text { traits }\end{array}$ & $\begin{array}{c}\text { Correlation with ideal } \\
\text { tourist destination }\end{array}$ \\
\hline honest & $\mathbf{. 3 7 1}$ \\
\hline friendly & .370 \\
\hline sexy & .352 \\
\hline smart & .330 \\
\hline humorous & .312 \\
\hline brave & .308 \\
\hline warm-hearted & .301 \\
\hline passionate & .287 \\
\hline educated & .282 \\
\hline unique & .272 \\
\hline carefree & .254 \\
\hline tolerant & .243 \\
\hline colorful & .229 \\
\hline polite & .226 \\
\hline selfless & .205 \\
\hline dynamic & .202 \\
\hline peaceful & .198 \\
\hline optimistic & .176 \\
\hline generous & .171 \\
\hline straightforward & .160 \\
\hline individualistic & .150 \\
\hline perfectionist & .143 \\
\hline industrious & .140 \\
\hline idealistic & .137 \\
\hline
\end{tabular}

Pearson correlation coefficients $(p \leq 0.05)$

The influence of culture personality on the evaluation of France as an ideal tourist destination has also been examined with the help of regression models. Regression analysis was run on the culture personality trait variables, and results are shown in Table 3. We identified the most fitting step-by-step model (partial F-test with stepwise method) for the regression procedure. This method alternately enters and removes variables from the list of independent variables with respect to the partial correlation coefficients. The stop-criterion is the exit of F-statistics and significance values from the pre-de- termined interval. In our case, it is adequate to apply the stepwise technique, because the size of the sample is much bigger than the number of explanatory variables. The stepwise regression model may be problematic for some reasons (e.g. Laurent, 1996). These were eliminated with utmost care: possible logical errors were controlled (based on our preliminary research), and the stability of the results was checked on several occasions by assessing cross-validity, so we divided the database into an estimate and a validity sample.

TABLE 3: Relationship between France's culture personality and France being an ideal tourist destination

\begin{tabular}{|l|c|c|}
\hline & \multicolumn{2}{|c|}{$\begin{array}{c}\text { Model } \\
\text { Ideal tourist } \\
\text { destination }\end{array}$} \\
\hline Independent variables & $\boldsymbol{\beta}$ & $\mathbf{t}$ \\
\hline Honest & 0.18 & 3.028 \\
\hline Sexy & 0.15 & 2.465 \\
\hline Brave & 0.15 & 2.473 \\
\hline Passionate & 0.13 & 2.174 \\
\hline Educated & 0.13 & 2.123 \\
\hline Friendly & 0.12 & 1.898 \\
\hline Stable & - & - \\
\hline F & $\mathbf{1 3 . 8 1 9}$ \\
\hline $\mathbf{R}^{\mathbf{2}}$ & \multicolumn{2}{|c|}{$\mathbf{0 . 2 6}$} \\
\hline Adjusted $\mathbf{R}^{\mathbf{2}}$ & $\mathbf{2 . 2 4}$ \\
\hline
\end{tabular}

Based on the results of the regression analysis, we can conclude that, in the case of tourist evaluation, six variables may be included in the model after filtering the partial effects. As an important result, among the personality traits besides the hardly explainable "humble collectivism" factor, variables in the "life approach" dimension were also excluded from the model. In evaluating France as an ideal tourist destination, honesty is the most important variable with the highest $\beta$ value. From the tourist point of view, sexiness, being educated, friendliness, bravery, and passion are the most determinant traits. 


\section{DISCUSSION AND LIMITATIONS}

Travel motivations of respondents with different demographic characteristics, such as specific age groups (e.g. Irimiás, Mitev \& Michalkó, 2016), can vary. In our case, business faculty students can have specific attitudes and motives for their choice of tourism destination. Perceived culture personality might play an important role in this process. Our research focuses on this field in an attempt to develop a relevant measurement tool.

First, the study summarized the results of a culture personality scale development process. From the methodological point of view, this means an exploratory phase to generate relevant items and refine them. As a result of this work, a 51-item bipolar scale was developed and translated into three languages (Hungarian, French, English). Following quantitative data collection, we managed to identify some dimensions that seem to be stable across different factor analyses. These, per se, can be useful to get a deeper insight into the antecedents of the evaluation of cultures as tourist destinations. Beside the factors named "competence", "life approach", "aura" and "interpersonal approach", "rectitude" was also proved to be stable but it requires further item generation and purification.

Next, the study investigated the culture personality traits of France and Hungary among French and Hungarian respondents. The analysis shows that French and Hungarian university students perceive both their own and the other group's culture personality in different ways. In the case of the French culture, 22 personality traits were perceived significantly differently by the two respondent groups. When evaluating the Hungarian culture, 24 personality traits were rated significantly differently. Half of the significant differences were more positive as an in-group evaluation, that is, when someone evaluates his or her own culture, while the other half of the items were more negative. This means that there is a huge gap between how we perceive a culture when we are members of it and when we look at it as outsiders, and it can have an impact on the appropriate communication in two ways. Organizations responsible for country image communication could either rely on the more positively perceived personality characteristics or attempt to eliminate the negative perceptions.

These results can also be used for international communication activities related to cultures where (due to the sample composition) the target group is university students, e.g. international studies, educational tourism.

Finally, the study identified the most important personality traits that have a significant effect on the evaluation of culture as a tourist destination. Due to the sample size we have analyzed this relationship on the French culture. Hungarian students' choice is mostly dependent on their perceptions of the culture according to honesty, sexiness, education, friendliness, bravery, and passion. These characteristics do not belong to only one or two dimensions of culture personality we revealed via exploratory factor analysis. While half of the significant traits represent the "aura" dimension, "competence", "interpersonal approach", and "rectitude" also have their role in the evaluation. As the characteristics identified above explain $24 \%$ of the variation of the evaluation, the responsible managers should take them into account in their marketing communication plan of destinations.

Our study has limitations due to the nature and size of the sample; however, it provides inputs for further scale developments and measurement related to issues in the field of country image. The results concerning perceived culture personality could be biased mainly on account of the sample size and composition. The students pursuing business education can have different reference points when evaluating cultures to visit and can perceive culture personalities through dimensions differing from those perceived by other members of society. 
Moderating variables are planned to be used for further research. Peer influence, self-esteem, etc., for example, could influence the relationship between culture personality and the evaluation of a destination. Self-congruity theory raises another research question, namely, what plays an important role in receiving a more favorable evaluation: the more positive perceptions of a culture's personality or the similarity between the personality of the targeted person and the culture in question. Further testing and refinement of the scale is a priority among research directions. Based on the results, the finalization and international validation of the $C P$ scale is the next phase in the process to achieve the possibility of international comparison. Be- yond the methodological issues, the role of culture personality should be measured within the scope of a broader concept, such as country equity or country brand identity. In the case of countries with multiple nationalities, it can be an interesting research question to identify the contribution of each nationality to the perceived culture personality of the whole country and the dynamics involved.

\section{Acknowledgment}

The authors would like to thank the anonymous reviewers for their valuable comments and suggestions for improving the quality of the paper.

\section{References}

1. Aaker, J. (1997). Dimensions of Brand Personality. Journal of Marketing Research, 34(3), 347-356.

2. Allport, G. W. (1937). Personality: a psychological interpretation. New York, NY: Holt and Company.

3. Allport, G. W., \& Odbert, H. S. (1936). Trait-names: A psycho-lexical study. Psychological Monographs, 47(1), 1-171.

4. Azoulay, A., \& Kapferer, J. N. (2003). Do brand personality really measures brand personality?. Brand Management, 11(2), 143-155.

5. Berács, J., \& Gyulavári, T. (1999). Magyarország és Svédország termékeinek megítélése a budapesti lakosság körében. Marketing \& Menedzsment, 33(6), 31-38.

6. Berács, J., Gyulavári, T., Heslop, L. A., \& Papadopoulos, N. (2000). An Exploratory Study on the Role of Familiarity in Product Evaluations. 29 ${ }^{\text {th }}$ EMAC Conference 'Marketing in the New Millenium'. Rotterdam: Erasmus University.

7. Bodnár, D., Jászberényi, M., \& Ásványi, K. (2017). Sustainability in museums of Budapest, an exploratory research. Tourism 2017 Conference - Sustaining sustainability cultural heritage and cultural capital. Veszprém: University of Pannonia.

8. Búrcio, C., Silva, R. \& Salgueiro, M. F. (2014). The direct and indirect impact of country personality on behavioral intentions for traveling: the full mediation effect of the affective country image. International Journal of Business and Economic Development, 2(3), 1-12.

9. Cattel, R. B. (1945). The principal trait clusters for describing personality. Psychological Bulletin, 42(3), 129-161.

10. Cattel, R. B., Eber, H. W., \& Tatsuoka, M. M. (1970). Handbook for the Sixteen Personality Factor Questionnaire (16PF), Champaign, Illinois: Institute for Personality and Ability Testing.

11. Churchill, G. A. Jr. (1979). A Paradigm for Developing Better Measures of Marketing Constructs. Journal of Marketing Research, 16(1), 64-73.

12. D'Astous, A., \& Boujbel, L. (2007). Positioning countries on personality dimensions: Scale development and implications for country marketing. Journal of Business Research, 60(3), 231-239.

13. Fiske, D. W. (1949). Consistency of the factorial structures of personality ratings from different sources. The Journal of Abnormal and Social Psychology, 44(3), 329-344. 
14. Gyulavári, T., Mitev, A., Neulinger Á., Neumann-Bódi, E., Simon, J., \& Szűcs, K. (2014). A marketingkutatás alapjai. Budapest: Akadémiai Kiadó.

15. Heslop, L. A., Papadopoulos, N., \& Bamossy, G. J. (1993). Country and product perceptions: measurement scales and image interactions. In: W. Fred Van Raaij \& Gary J. Bamossy (Eds.). European Advances in Consumer Research Volume 1, (pp. 198-205). Provo, UT: Association for Consumer Research.

16. Hofmeister, T. Á., Neulinger, Á., \& Kunsági, A. (2002). Brand Personality Research in a Different Cultural Setting. Annual Conference of the Academy of Marketing. Nottingham.

17. Hosany, S., Ekinci, Y., \& Uysal, M. (2006). Destination image and destination personality: An application of branding theories to tourism places. Journal of Business Research, 59(5), 638-642.

18. Irimiás, A., Mitev, A., \& Michalkó, G. (2016). Demographic characteristics influencing religious tourism behaviour: Evidence form a Central-Eastern-European country. International Journal of Religious Tourism and Pilgrimage, 4(4), 17-32.

19. Jenes, B. (2012). Theoretical and Practical Issues in Measuring Country Image. Doctoral Dissertation. Budapest: Corvinus University of Budapest.

20. John, O. P., \& Srivastava, S. (1999). The Big Five Taxonomy, History, Measurement and Theoretical Perspective. In: J. Pervin (Ed.). Handbook of Personality, Theory and Research. $2^{\text {nd }}$ ed. (pp. 102-138), New York, NY: Guilford Press.

21. Keller, K. (2017). A turizmusmarketing környezete. In: K. Lőrincz \& J. Sulyok (Eds.). Turizmusmarketing, (pp. 39-61). Budapest: Akadémiai Kiadó.

22. Laurent, G. (1996). Regression analysis. Ph.D. course material. Budapest: Corvinus University of Budapest.

23. Linden, D. V. D., Nijenhuis, J. T., \& Bakker, A. B. (2010). The General Factor of Personality: A meta-analysis of Big Five intercorrelations and a criterion-related validity study. Journal of Research in Personality, 44(3), 315-327.

24. Malota, E., \& Gyulavári, T. (2012). Culture-Personality of France and Hungary - scale development and results. Global Business Conference: To standardize or not to standardize? Zadar: Innovation Institute.

25. Malota, E., \& Gyulavári, T. (2014). Az észlelt kultúraszemélyiség és hatása az az ország turisztikai és üzleti célpontként való megítélésére. Vezetéstudomány, 45(1), 2-13.

26. Malota, E. (2003). Consumer ethnocentrism; the effect of stereotypes, ethnocentrism and country of origin image on the choice between foreign and domestic products. Doctoral Dissertation. Budapest: Corvinus University of Budapest.

27. McEnally, M., \& de Chernatony, L. (1999). The evolving nature of branding: consumer and managerial consideration. Academy of Marketing Science Review, 2(1), 1-26.

28. Murphy, L., Benckendorff, P., \& Moscardo, G. (2007). Linking Travel Motivation, Tourist Self-Image and Destination Brand Personality. Journal of Travel \& Tourism Marketing, 22(1), 45-59.

29. Papadimitriou, D., Apostolopoulou, A., \& Kaplanidou, K. (2013). Destination Personality, Affective Image, and Behavioral Intentions in Domestic Urban Tourism. Journal of Travel Research, 54(3), 302-315.

30. Papadopoulos, N., \& Heslop, L. A. (2014). Product-country images: Impact and role in international marketing. London: Routledge.

31. Papp-Váry, Á. F. (2008). „Márkás országok” - márkamodellek és márkaérték-számítás az országok esetében. In: L. Józsa \& M. Csath (Eds.). Vállalati növekedés - változó menedzsment/marketing. Győr-Székesfehérvár: SZIE/KJF.

32. Péter, E., Németh, K., \& Kaszás, N. (2014a). More can sometimes be less - in other words, what and how much do Hungarians consume?. In: B. Szabolcs (Ed.). 20 th Youth Scientific Forum, (pp. 286-296). Keszthely: University of Pannonia Georgikon Faculty. 
33. Péter, E., Németh, K., \& Kaszás, N. (2014b). Cafeteria plan as a possibility in corporate culture: $20^{\text {th }}$ Youth Scientific Forum. In: B. Szabolcs (Ed.). 20 2 Youth Scientific Forum, (pp. 273-285). Keszthely: University of Pannonia Georgikon Faculty.

34. Rossiter, J. R. (2002). The C-OAR-SE procedure for scale development in marketing. International Journal of Research in Marketing, 19(4), 305-335.

35. Roth, K.P., \& Diamantopoulos, A. (2009). Advancing the country image construct. Journal of Business Research, 62(7), 726-740.

36. Sun, Q. (2016). The Analytical Model of Country Resources, Country Image, and Foreign Direct Investment: The Country Branding Implications. In: K. Kim (Ed). Celebrating America's Pastimes: Baseball, Hot Dogs, Apple Pie and Marketing? (pp. 807-808). Boston, MA: Springer International Publishing.

37. Tupes, E. C., \& Christal, R. E. (1992). Recurrent Personality Factors Based on Trait Ratings. Journal of Personality, 60(2), 225-251.

38. Usakli, A., \& Baloglu, S. (2011). Brand personality of tourist destinations: An application of self-congruity theory. Tourism Management, 32(1), 114-127.

39. Zhang, H., Fu, X., Cai, L. A., \& Lu, L. (2014). Destination image and tourist loyalty: A meta-analysis. Tourism Management, 40(1), 213-223. 